\title{
Managing COVID-19 in resource-limited settings: critical care considerations
}

\author{
Wen Ting Siow ${ }^{1,2^{*}}$, Mei Fong Liew ${ }^{1,2}$, Babu Raja Shrestha ${ }^{3}$, Faisal Muchtar ${ }^{4}$ and Kay Choong See ${ }^{1}$
}

The 2019 coronavirus (COVID-19) pandemic has now involved numerous low-to-middle-income countries (LMICs). The healthcare systems in LMICs face serious constraints in capacity and accessibility during normal times. This would be aggravated during an outbreak, leading to worse clinical outcomes. Moreover, 69\% of the global population aged 60 and above live in LMICs. These older persons are at increased risk of severe COVID-19 and mortality [1].

LMICs lack time and finances for swift uptake of new technologies (e.g., rapid test kits, vaccines, and antivirals). From a more urgent and pragmatic perspective, we believe creative use of existing resources and repurposing others for human medical care are needed (Table 1). We acknowledge that our suggestions may be perceived as controversial, and we wish to emphasize that maximization of conventional healthcare assets should always be done before turning to unconventional solutions.

\section{Infrastructure}

Anticipation of an impending outbreak helps vital preparation. Unfortunately, during the COVID-19 pandemic, there is little time to construct new infrastructure. The World Health Organization (WHO) has recommended airborne isolation, but isolation facilities are limited. Industrial exhaust fans have been used to convert existing normal pressure single rooms to negative pressure rooms to increase isolation [2]. This approach is relatively quick and may be used for creating more negative pressure intensive care unit (ICU) beds. Alternatively,

\footnotetext{
*Correspondence: siow_wen_ting@nuhs.edu.sg

${ }^{1}$ Division of Respiratory and Critical Care Medicine, University Medicine

Cluster, National University Health System, 1E Kent Ridge Rd, Singapore 119228, Singapore

${ }^{2}$ Fast and Chronic Programmes, Alexandra Hospital, National University Health System, Queenstown, Singapore

Full list of author information is available at the end of the article
}

confirmed cases can be cohorted in open ICUs with adequate ventilation.

Opening field hospitals in large public spaces (e.g., stadiums) allows for triaging and managing stable patients and decongest other hospitals. Local networks between smaller district hospitals and larger tertiary centers can be established to facilitate patient transfers, as smaller hospitals can be easily overwhelmed. Well patients with COVID-19, instead of being quarantined in hospitals, can be quarantined in specially designated facilities, such as a hotel. If communication systems are available, well patients could be sent home and monitored remotely.

Makeshift acute or critical care units can be set up in operating theaters and clinic spaces to cope with increasing numbers of critically ill patients. This can be achieved by reducing non-essential services such as elective surgeries and outpatient clinics.

\section{Patient monitoring or testing}

For LMICs, focused testing on symptomatic patients instead of random screening would place less strain on the healthcare system. Rapid test kits are an option to allow LMICs to perform diagnostic tests faster, but this would require international health organizations to transfer knowledge and test kits. It may be necessary to isolate an entire community for containment.

Radiological investigations and laboratory support would also be stretched beyond capacity. Physicians may need to rely mainly on bedside clinical examination. If available, bedside point-of-care ultrasonography can yield significant amounts of information. Early clinical detection and admission to the correct facility can help with right-siting before confirmatory tests are out, reducing nosocomial and community spread. Simple scoring systems, such as the qSOFA score, can be harnessed to detect deteriorating patients [3]. 
Table 1 Managing COVID-19 when resources are limited

\begin{tabular}{|c|c|c|}
\hline Resource limitation & Specific challenges & Optimal use of existing resources \\
\hline Infrastructure & $\begin{array}{l}\text { Limited number of isolation beds } \\
\text { (negative pressure and normal } \\
\text { pressure) for suspected and } \\
\text { confirmed COVID-19 patients }\end{array}$ & $\begin{array}{l}\text { - Central monitoring of bed } \\
\text { numbers for better visibility } \\
\text { and allocation } \\
\text { - Inclusion of private hospitals } \\
\text { and military hospitals in total } \\
\text { bed count } \\
\text { - Transforming clinics into inpatient } \\
\text { care units } \\
\text { - Home as hospital concept with } \\
\text { HCW monitoring less ill patients } \\
\text { in the community using telemedicine } \\
\text { - Mounting fever tents outside } \\
\text { emergency departments to } \\
\text { better triage and segregate } \\
\text { symptomatic patients } \\
\text { - Utilize military hospital assets } \\
\text { (land-based units; hospital ships) } \\
\text { - Use diesel-based electrical } \\
\text { generators to cope with energy } \\
\text { demands } \\
\text { - Early engagement of community } \\
\text { leaders } \\
\text { - Isolating communities instead } \\
\text { of individuals in case of local } \\
\text { outbreaks }\end{array}$ \\
\hline
\end{tabular}

Monitoring/testing Limited number of accredited test labs/sites, especially in suburbs and regional hospitals Lack of point-of-care-certified test kits at the frontlines and community Lack of sufficient mobile test sites/clinics
- International health organizations should coordinate rapid technology transfer to LMICs. Allowance and early acceptance of rapid test kits

- Provide 1 low-cost thermometer per family unit for self-monitoring of temperature

- Rely on clinical parameters and examination rather than blood tests to preserve lab capacity (e.g., capillary refill time instead of lactate, qSOFA score to predict deterioration)

- Noninvasive manual methods, e.g., manual BP rather than IA lines; $\mathrm{SpO} 2$ rather than $\mathrm{ABG}$

- Point-of-care ultrasound rather than X-rays/CT scans

- Use transport ventilators and anesthesia units

- Splitting ventilators (i.e., attaching up to 4 COVID-19 patients to the same ventilator), using pressure cycling rather than volume cycling, and with continuous mandatory ventilation

- Improvised CPAP (iCPAP) to replace invasive ventilation

- Using bag-valve-ETT with PEEP valves

- Use portable oxygen concentrators rather than tanks, especially in field hospitals

- Early use of prone positioning
Repurposing other resources for human medical care

- Opening field hospitals by converting public facilities (e.g., sports facilities, stadiums, soccer fields) and building open tents to house noncritically ill patients and those who cannot stay at home. Use of industrial fans in these spaces to ensure good ventilation

- Tap on portable power and solar generators for electricity to run medical equipment

- Conversion of public and commercial facilities (e.g., hotel rooms, chalets, hostels) into quarantine facilities for well patients

- Mobilizing the community and restaurants to help prepare and deliver food for HCWs and patients in quarantine facilities - Use of industrial exhaust fans to convert single rooms with normal pressure to negative pressure rooms for isolation in hospitals, especially for ICU

- Conversion of veterinary hospitals and deploying medical personnel to accept non-critically ill patients

- Cohort all confirmed cases in wellventilated open cubicles to free-up isolation beds for suspected cases

- Usage of veterinary facilities including animal devices used for patient monitoring and animal ultrasound devices

- Mobilize military forces, community partners, schools, and volunteers to help establish mobile test sites for symptomatic patients. These patients can be issued a stay-home notice after the test. Establish a call-center to rapidly inform patients of results and follow-up action (e.g., contact-tracing)

- Non-medical factories or production lines to manufacture medical equipment like face masks, ventilators, monitoring devices, and intravenous fluids - Usage of suitable veterinary equipment, e.g., ventilators, IV pumps, and approved drugs, e.g., analgesics, antibiotics, and consumables for wound care 
Table 1 Managing COVID-19 when resources are limited (Continued)

\begin{tabular}{|c|c|c|c|}
\hline Resource limitation & Specific challenges & Optimal use of existing resources & $\begin{array}{l}\text { Repurposing other resources } \\
\text { for human medical care }\end{array}$ \\
\hline & & $\begin{array}{l}\text { if oxygenation needs exceed } \\
\text { available inspired oxygen } \\
\text { supply, even in patients who } \\
\text { are not on invasive mechanical } \\
\text { ventilation } \\
\text { - Enteral hydration, vasopressors } \\
\text { (e.g., NG midodrine), antimicrobials } \\
\text { rather than using intravenous } \\
\text { formulations } \\
\text { - Avoid expending resources } \\
\text { on experimental therapies }\end{array}$ & \\
\hline $\begin{array}{l}\text { Personal protective } \\
\text { equipment }\end{array}$ & Insufficient PPE & $\begin{array}{l}\text { - Re-use surgical masks and } \\
\text { goggles } \\
\text { - Sharing of certain types of } \\
\text { PPE like googles after disinfection } \\
\text { - Ultraviolet light decontamination } \\
\text { of medical equipment, re-used } \\
\text { surgical masks and goggles } \\
\text { - Use washable gowns and gloves } \\
\text { - Use alcohol-based rubs and } \\
\text { spirits rather than clean water, } \\
\text { which may be in short supply } \\
\text { - Assemble reusable elastometric } \\
\text { respirators to replace N95 } \\
\text { respirators }\end{array}$ & $\begin{array}{l}\text { - Use protective face masks, } \\
\text { respirators, and gowns from } \\
\text { other industries, e.g., food } \\
\text { industries, manufacturing plants, } \\
\text { construction, and mining } \\
\text { - Getting factories and production } \\
\text { lines to manufacture PPE }\end{array}$ \\
\hline Personnel & Insufficient staff & $\begin{array}{l}\text { - Enrolling of dentists, paramedical } \\
\text { personnel, village health attendants } \\
\text { - Enrolling of military medical } \\
\text { personnel } \\
\text { - Enrolling of medical, nursing, } \\
\text { and allied health students to } \\
\text { help with pandemic medical } \\
\text { treatment } \\
\text { - Designate convalescent HCW to } \\
\text { provide care for confirmed } \\
\text { COVID-19 patients } \\
\text { - Enroll convalescent patients to } \\
\text { volunteer at as health attendants }\end{array}$ & $\begin{array}{l}\text { - Enrolling veterinary HCWs and } \\
\text { medical students by providing } \\
\text { them with crash courses to help } \\
\text { stem manpower shortages in } \\
\text { hospitals } \\
\text { - Enrolling non-medical personnel } \\
\text { to act as health attendants, e.g., to } \\
\text { do temperature taking and man } \\
\text { screening stations. This will relieve } \\
\text { workload of existing healthcare } \\
\text { personnel }\end{array}$ \\
\hline Information & $\begin{array}{l}\text { Uncertainty and confusion over } \\
\text { testing, triage, and treatment }\end{array}$ & $\begin{array}{l}\text { - Setting up protocols and } \\
\text { checklists to standardized } \\
\text { medical care that are simple, } \\
\text { easy to teach. Avoid overuse } \\
\text { of non-EBM methods } \\
\text { - Promotion of simplified EBM } \\
\text { scores for risk stratification, } \\
\text { e.g., qSOFA for LMICs } \\
\text { - Encourage uptake of } \\
\text { teleconferencing platforms } \\
\text { to discuss and learn about } \\
\text { new updates from } \\
\text { international medicine } \\
\text { communities }\end{array}$ & $\begin{array}{l}\text { - Use mobile/SMS technology to } \\
\text { provide simple policy and health } \\
\text { updates to HCWs/public, besides } \\
\text { emails and paper-based mailers }\end{array}$ \\
\hline Transport & $\begin{array}{l}\text { Insufficient transport options } \\
\text { for patients }\end{array}$ & $\begin{array}{l}\text { - Inclusion of public, } \\
\text { commercial, and military } \\
\text { healthcare transport vehicles }\end{array}$ & $\begin{array}{l}\text { - Getting nonmedical transport } \\
\text { services to become ambulances }\end{array}$ \\
\hline
\end{tabular}

$C T$ computed tomography, ETT endotracheal tube, HCW healthcare worker, LMIC low-to-middle-income country, PEEP positive end expiratory pressure, PPE personal protective equipment

\section{Treatment}

Hospital ventilators will likely be in shortfall. To supplement ventilators, anesthesia units in operating theaters and transport ventilators can be used. Improvised continuous airway pressure (iCPAP) ventilation systems [4] or bubble continuous airway pressure for children [5] can be employed when there is a dire shortage. The addition of high-efficiency particulate air (HEPA) filters to the expiratory limb of the circuit can help minimize aerosolization if the ventilator does not have a closed 
circuit. Other creative approaches include splitting a ventilator to support several patients simultaneously by using T-tubes and pressure-cycled ventilation [6-8].

Proning positioning has been reported to work in critically ill COVID-19 patients with moderate-to-severe acute respiratory distress syndrome [1]. Patients who are moderately hypoxemic can be proned early to improve oxygenation if oxygen supplies are limited, presumably even if they are not invasively ventilated [9]. Other approaches to save ICU resources include using enteral vasopressors, such as midodrine for hypotensive patients, instead of intravenous formulations [10]. In states of emergencies, veterinary supplies, such as cleaning solutions, syringe pumps, and even ventilators, could be mobilized to augment hospital stocks.

Ultimately, there still needs to be fair and ethical resource stewardship [11].

\section{Personal protective equipment (PPE)}

Healthcare workers (HCWs) working on the frontlines need to be protected adequately, or they risk catching COVID-19 and even dying [12]. This is also applicable to personnel such as ambulance drivers and military troops. PPE can be reused to reduce waste [13] and preserve existing stocks. Certain types of PPE like goggles may be shared after disinfection. Deploying reusable powered air-purifying respirators is an option. Other innovative approaches include testing, validating, and assembling simple reusable elastometric respirators to replace N95 respirators [14].

If prior infection can be proven to confer immunity, other approaches to reduce PPE use can include deploying convalescent HCWs to care for confirmed COVID19 patients and enrolling convalescent patients to volunteer in healthcare.

\section{Personnel}

To cope with healthcare demands, active recruitment and training of healthcare personnel should be done concurrently. Besides recalling HCWs on leave, recruitment and redeployment from different sectors (e.g., dentists, paramedics, medical students, military personnel) and even recalling retired personnel may be required. Laypeople, including carers, can be recruited into the hospital after training to provide basic care for patients. Interprofessional skill training should also be done among nurses and doctors. For example, surgeons can be taught simple ventilator care. Sharing simple treatment protocols will aid those who have been redeployed.

\section{Information}

In a large-scale pandemic, crucial information about the disease and workflows are constantly evolving. There is a need for information to be disseminated and assimilated rapidly on the ground to prevent delays. An agile system of information dissemination should include mobile phones via text messages or emails and paperbased mailers. Protocols and checklists will also help in standardizing medical care and reducing wastage.

\section{Transport}

Harnessing non-medical transport services, such as private-hire and public vehicles and military vehicles, can help improve accessibility to healthcare in LMICs. These vehicles can help ferry unwell patients from the suburbs to regional or central hospitals and reduce delays to medical care. A caveat would be that these transport vehicles need to be thoroughly cleaned following transport [15].

\section{Acknowledgements}

Not applicable.

\section{Authors' contributions}

Wen Ting Siow drafted and revised the article and table. Mei Fong Liew revised, proof-read, and edited the table and article. Babu Raja Shrestha revised the table and proof-read the article. Faisal Muchtar proof-read and revised the table. Kay Choong See conceptualized the letter and drafted and revised article. The author(s) read and approved the final manuscript.

Funding

Not applicable.

\section{Availability of data and materials}

Data sharing is not applicable to this article as no datasets were generated or analyzed during the current study.

Ethics approval and consent to participate Not applicable.

\section{Consent for publication}

Not applicable.

\section{Competing interests}

The authors declare that they have no competing interests.

\section{Author details}

${ }^{1}$ Division of Respiratory and Critical Care Medicine, University Medicine Cluster, National University Health System, 1E Kent Ridge Rd, Singapore 119228, Singapore. ${ }^{2}$ Fast and Chronic Programmes, Alexandra Hospital, National University Health System, Queenstown, Singapore. ${ }^{3}$ Department of Anaesthesia, Kathmandu Medical College and Teaching Hospital, Kathmandu, Nepal. ${ }^{4}$ Department of Anesthesiology, Intensive Care and Pain

Management, Medical Faculty, Hasanuddin University, Makassar, South Sulawesi, Indonesia.

Received: 31 March 2020 Accepted: 14 April 2020

Published online: 22 April 2020

References

1. Yang $X, Y u Y, X u$ J, et al. Clinical course and outcomes of critically ill patients with SARS-CoV-2 pneumonia in Wuhan, China: a singlecentered,retrospective, observational study. Lancet Respir Med. 2020;S22132600(20):30079-5. Epub ahead of print. Erratum in: Lancet Respir Med. 2020; 8(4):e26. https://doi.org/10.1016/S2213-2600(20)30079-5.

2. Gomersall CD, Tai DY, Loo S, Derrick JL, Goh MS, Buckley TA, et al. Expanding ICU facilities in an epidemic: recommendations based on experience from the SARS epidemic in Hong Kong and Singapore. Intensive Care Med. 2006;32(7):1004-13.

3. Rudd KE, Seymour CW, Aluisio AR, Augustin ME, Bagenda DS, Beane A, et al. Association of the Quick Sequential (sepsis-related) Organ Failure 
Assessment (qSOFA) score with excess hospital mortality in adults with suspected infection in low- and middle-income countries. JAMA. 2018; 319(21):2202-11.

4. Milliner BH, Bentley S, DuCanto J. A pilot study of improvised CPAP (iCPAP) via face mask for the treatment of adult respiratory distress in low-resource settings. Int J Emerg Med. 2019;12(1):7.

5. Chisti MJ, Salam MA, Smith JH, Ahmed T, Pietroni MAC, Shahunja KM, et al. Bubble continuous positive airway pressure for children with severe pneumonia and hypoxaemia in Bangladesh: an open, randomised controlled trial. Lancet. 2015;386(9998):1057-65.

6. Branson RD, Blakeman TC, Robinson BR, Johannigman JA. Use of a single ventilator to support 4 patients: laboratory evaluation of a limited concept. Respir Care. 2012;57(3):399-403.

7. Neyman G, Irvin CB. A single ventilator for multiple simulated patients to meet disaster surge. Acad Emerg Med. 2006;13(11):1246-9.

8. Smith R, Brown JM. Simultaneous ventilation of two healthy subjects with a single ventilator. Resuscitation. 2009;80(9):1087.

9. Scaravilli V, Grasselli G, Castagna L, Zanella A, Isgro S, Lucchini A, et al. Prone positioning improves oxygenation in spontaneously breathing nonintubated patients with hypoxemic acute respiratory failure: a retrospective study. J Crit Care. 2015;30(6):1390-4.

10. Whitson MR, Mo E, Nabi T, Healy L, Koenig S, Narasimhan M, et al. Feasibility, utility, and safety of midodrine during recovery phase from septic shock. Chest. 2016;149(6):1380-3.

11. Powell T, Christ KC, Birkhead GS. Allocation of ventilators in a public health disaster. Disaster Med Public Health Preparedness. 2008;2:20-6.

12. Wang J, Zhou M, Liu F. Reasons for healthcare workers becoming infected with novel coronavirus disease 2019 (COVID-19) in China. J Hosp Infect. 2020;S0195-6701(20):30101-8. https://doi.org/10.1016/j.jhin.2020.03.002. Epub ahead of print.

13. Prevention CfDCa. Recommended guidance for extended use and limited reuse of N95 filtering facepiece respirators in healthcare settings. 2020. Available from: https://www.cdc.gov/niosh/topics/hcwcontrols/ recommendedguidanceextuse.html.

14. Hospital BCs. Making your own reusable elastomeric respirator for use during COVID-19 viral pandemic N95 shortage 2020. Available from: https:// www.youtube.com/watch?v=Es iY 5 WJdml.

15. Liew MF, Siow WT, Yau YW, See KC. Safe patient transport for COVID-19. Crit Care. 2020;24(1):94.

\section{Publisher's Note}

Springer Nature remains neutral with regard to jurisdictional claims in published maps and institutional affiliations. 